\author{
Федорова Наталья Владимировна, \\ к.Т.н., доцент, Иркутский государственный университет путей сообщения, \\ УПРАВЛЕНИЕ ПРОФЕССИОНАЛЬНЫМИ РИСКАМИ \\ КАК ФАКТОР БЕЗОПАСНОСТИ ТРУДА
}

\title{
THE MANAGEMENT OF PROFESSIONAL RISKS AS A FACTOR OF SAFETY
}

\section{Fedorova N.V.}

\begin{abstract}
Аннотация. В статье выполнен анализ нормативно-правовых документов, связанных с внедрением риск - ориентированного подхода в области охраны, в котором значительная роль отведена эфффективному управлению профессиональными рисками, что представляется актуальным в сфере безопасности труда.

Ключевые слова: профессиональные риски, безопасные условия труда, средства индивидуальной защиты, охрана труда

Abstract. The article analyzes the normative legal documents related to the introduction of risk - based approach in the field of protection, in which a significant role is assigned to the effective management of professional risks, which seems relevant in the field of occupational safety. protection

Keywords: professional risks, safe working conditions, personal protective equipment, labor

При осуществлении профессиональной деятельности каждый работник находится в условиях, представляющих собой сочетание факторов производственной среды и трудового процесса и способных оказывать влияние на работоспособность и здоровье человека. Одним из основных приоритетов в области охраны труда на предприятии является минимизация влияния вредных и опасных фракторов, способствующих возникновению профессиональных рисков.

Под профессиональным риском понимают вероятность причинения вреда здоровью в результате воздействия вредных и (или) опасных производственных фракторов при исполнении работником обязанностей по трудовому договору или в иных случаях, установленных Трудовым Кодексом или другими фредеральными законами [1].

Различают риск проявленный и скрытый. К проявленному риску относят производственный травматизм и профессиональные заболевания. Следствием производственного травматизма могут быть временная или полная утрата трудоспособности, смертельный исход. В свою очередь профессиональные заболевания могут повлечь полную или частичную утрату трудоспособности.

Скрытый риск порождает общее нездоровье работника и складывается из профессиональных заболеваний, связанных либо с одним фактором трудовой деятельности, либо обусловленных несколькими фракторами, как рабочей среды, так и внешними. Кроме того, к факторам скрытого риска могут быть от-
\end{abstract}


несены общие заболевания, не имеющие непосредственной связи с трудовой деятельностью, но осложненные профессиональными факторами.

Скрытый риск способствует росту общей заболеваемости, снижению иммунитета, психологическим стрессам, а также является причиной различных заболеваний, заканчивающихся летальным исходом. Поэтому при оценке профессионального риска необходимо уделять внимание не только явным, но и скрытым фракторам, которые можно выявить при организованных работодателем периодических медицинских осмотрах.

Оценка и управление профессиональными рисками является составной частью специальной оценки условий труда в организации, основная задача которой заключается в улучшении условий труда и производственной среды. Своевременно принятые меры помогут избежать производственного травматизма, сохранить здоровье и безопасность.

Основополагающими принципами, регулирующими процесс оценки профессиональных рисков и управления ими, являются: предвидение, идентификация опасных фракторов, последующая оценка и контроль рисков на рабочих местах. Оценка профессионального риска состоит из 12 этапов [2]. Среди основных можно выделить:

- гигиеническую оценку и установление класса условий труда;

- анализ нормативно-технической документации на оборудование, процессы, материалы и т.п.;

- анализ профессиональной заболеваемости;

- анализ результатов периодических медицинских осмотров;

- анализ заболеваемости с временной утратой трудоспособности, инвалидности, смертности и т.п. по специальным программам;

- верификацию класса условий труда, определенного на этапе 1 , с учетом данных, полученных на этапах 2 - 5;

- расчет индекса профзаболеваний;

- шкалирование полученных данных по ЗВУТ, инвалидности, смертности, другим показателям;

- оценивание риска и определение категории доказанности риска.

В настоящее время управление производственными рисками является необходимой составляющей любой эффективной системы управления охраной труда. Основная цель оценки рисков заключается в выработке и принятии эффективных мер, необходимых для обеспечения безопасности и здоровья работников.

Превентивные мероприятия, направленные на снижение рисков, заключаются в своевременном информировании и обучении работников. Работники должны быть проинформированы о наличии в условиях производственной среды опасностей и рисков, а также о способах устранения или минимизации 
риска. Кроме того, большое внимание в области охраны труда следует уделять обязанностям и ответственности, как работников, так и работодателя.

В соответствии с действующим трудовым законодательством обязанности по обеспечению безопасных условий труда возлагаются на работодателя. Приказом Минздравсоцразвития РФ №181н утвержден перечень ежегодно реализуемых работодателем мероприятий по улучшению условий и охраны труда и снижению уровней профессиональных рисков. Конкретный перечень мероприятий определяется работодателем в зависимости от специфики хозяйственной деятельности. При этом работодатель не обязан поэтапно выполнять весь перечень. Также не предусмотрено, что мероприятия по улучшению условий и охране труда каждый год должны меняться.

В соответствии со ст. 226 ТК фринансирование мероприятий по улучшению условий и охраны труда осуществляется в размере не менее 0,2 \% суммы затрат на производство продукции (работ, услуг). Необходимо отметить, что государственные унитарные предприятия освобождены от выполнения данной обязанности и минимальный процент затрат для таких предприятий не установлен. Финансирование мероприятий по улучшению труда в бюджетных организациях осуществляется за счет средств, выделяемых на их содержание.

В свою очередь, работник должен:

- соблюдать требования охраны труда;

- правильно и своевременно использовать средства индивидуальной и коллективной защиты;

- проходить обучение безопасным методам и приемам выполнения работ и оказанию первой помощи пострадавшим на производстве, инструктаж по охране труда, стажировку на рабочем месте, проверку знаний требований охраны труда;

- выполнять профессиональные обязанности, не подвергая себя и других лиц риску возникновения несчастного случая на производстве или профессионального заболевания;

- незамедлительно сообщать работодателю о любой ситуации, потенциально представляющей опасность;

- содействовать работодателю в принятии мер, направленных на повышение безопасности и обеспечение охраны здоровья работников.

Министерство труда и социальной защиты РФ подготовило план мероприятий на 2018 год, в котором содержатся проекты поправок в трудовой кодекс и другие нормативно-правовые акты в области охраны труда [3]. Кроме того, разрабатываются рекомендации для работодателей по построению системы оценки рисков, которые будут содержать 72 метода оценки снижения рисков. Самым простым является регулярное использование для выявления рисков проверочных листов (чек-листы). 
Планируется, что переход к модели управления профессиональными рисками в области охраны труда будет завершен к концу 2018 г. Модель управления на основе оценки рисков подразумевает, что работодатель должен сам определять меры по устранению или снижению уровня выявленных на рабочих местах рисков с учетом их эффективности, от полного исключения опасной работы до использования средств индивидуальной защиты.

В данной концепции обеспечение работников средствами индивидуальной защиты (СИЗ) станет более адресным в соответствии с выявленным профессиональным риском. Риск-ориентированная модель выдачи средств защиты направлена на формирование новых подходов к разработке, производству и обеспечению работников разных отраслей средствами индивидуальной защиты. В будущем Минтруд планирует унифицировать типовые нормы выдачи СИЗ. Предполагается, что СИЗы будут распределены по группам в зависимости от воздействия вредных и опасных фракторов, видам работ, уровню загрязнения, и каждое СИЗ направлено на ограждение воздействия от совершенно определенных фракторов. Переход к новым принципам займет около 5 лет [4].

Преобразования в области охраны труда направлены на профилактику и учет рисков. Основная задача заключается в формировании превентивных мер, направленных на предотвращение производственного травматизма. Не маловажным представляется фрактор неформального отношения работодателя и работника к вопросам обеспечения безопасности труда на рабочем месте. Эфрфективное управление профессиональными рисками способствует сокращению не только человеческих, но и экономических потерь, обусловленных производственным травматизмом и профессиональной заболеваемостью.

\section{ЛИТЕРАТУРА}

1. Трудовой кодекс Российской Федерации от 30.12.2001№ 197-Ф3 (ред. от 05.02.2018 г.)

2. Р 2.2.2006-05. 2.2. Гигиена труда. Руководство по гигиенической оценке фракторов рабочей среды и трудового процесса. Критерии и классификация условий труда (утв. Главным государственным санитарным врачом РФ 29.07.2005 г.)

3. План мероприятий («дорожная карта») по актуализации, оптимизации и отмене обязательных требований в сфрере охраны труда (утв. протоколом заседания проектного комитета от 05.10.2017г. № 69 (12)).

4. http://www.przrf.ru/info/full/Ohrana-truda2/Ohrana-truda-v-2018-godu/ (дата обращения 14.04.2018г.). 